\title{
Academic Controversy In Macroeconomics: An Active And Collaborative Method To Increase Student Learning
}

Craig F. Santicola, Westmoreland County Community College, USA

\begin{abstract}
The literature indicates that there is a lack of learning outcomes in economics that can be attributed to the reliance on traditional lecture and the failure to adopt innovative instructional techniques. This study sought to investigate the student learning effects of academic controversy, a cooperative learning technique that shows promise in the area of economics instruction. A quasiexperimental pre-test, posttest design was used to compare a control group which received traditional lecture to a treatment group which received academic controversy lessons. Analysis of the data from the Test of Understanding in College Economics post-test suggests that the use of academic controversy had a positive impact on student learning. Implications of the study include providing a framework for academic controversy which shows promise for improving student learning in post-secondary macroeconomics.
\end{abstract}

Keywords: Academic Controversy; Collaborative Learning; Economics Education; Economics Instruction

\section{INTRODUCTION}

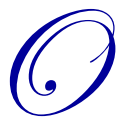

ver the years there have been several calls to improve post-secondary instruction to which educators have generally responded with teaching methods "designed to have students actively and cooperatively involved in the learning process" (Becker \& Watts, 1996, p. 2). Pedagogical practices that involve students while developing their learning of course material have been developed, tested, and reported in the academic literature.

While most disciplines frequently utilize a wide range of these active pedagogical techniques, there is one notable exception. In economics, the most dominant instructional technique across American post-secondary institutions is still the passive lecture. A nationwide survey of economics faculty found that approximately 83 percent of class time was spent on passive lecturing (Becker \& Watts, 1996). Moreover, the authors conducted follow-up surveys in 2000 and 2005 to find that a decade after their original report, 83 percent of class time was still spent lecturing (Becker \& Watts, 2008). The Becker and Watts surveys also revealed that economics faculty used innovative active learning strategies in only 6 percent of class time (Becker \& Watts, 1996).

However, the reliance on the passive form of lecture contradicts the inherent nature of economics. As an applied field, a widely accepted goal of the economic principles class is to "teach students to think like economists" (Siegfried, Bartlett, Hansen, Kelley, McCloskey \& Tietenberg, 1991). Yet, this involves more than students sitting passively. Colander \& McGoldrick (2009) concur, stating that the traditional teaching methods commonly used only touch on surface level learning (p. 85). Hansen, Salemi, \& Siegfried (2002) extend the argument, referring to the state of economics instruction as "a missed opportunity to improve economic literacy" in that there is no prospect for the development or application of thinking skills (p. 463).

Sadly, most students' enrolled in introductory economics end the course without having truly learned any economic theory nor developed any critical thinking ability (Walstad \& Rebeck, 2002; Hansen et al., 2002). Additionally, student evaluations of economic courses and instructors indicate that not only is the discipline among 
the lowest ranked, but it also discourages student enrollment by reputation alone (Cashin, 1990; Hansen, Salemi, \& Siegfried, 2002). Researchers attribute the lack of student outcomes and poor opinion on the reliance of traditional lecture and "underutilization of innovative teaching strategies" (Colander \& McGoldrick, 2009, p. 31).

To address concerns regarding the prevalence of traditional lecture, the associated lack of student learning, and the resistance to employ creative instructional techniques, the purpose of this study was to investigate the student learning effects of the cooperative learning technique, academic controversy, in post-secondary macroeconomics. The technique of academic controversy is particularly suited for this study in that economics involves analyzing all sides of an issue in order to make informed decisions while considering the potential sideeffects. Thus, the intellectual conflict, synthesizing of solutions, and reasoned judgment involved in academic controversy aligns with the goal of teaching students to "think like economists" (Siegfried, Bartlett, Hansen, Kelley, McCloskey \& Tietenberg, 1991). Further, the technique has not been previously examined in economics but has shown promise in the outcome of student learning.

\section{ACADEMIC CONTROVERSY PROCEDURE}

The academic controversy method utilizes cooperative student groups of four members to investigate an issue or topic. Each group is split into diads with each assigned to either the pro or con position. The goal is for students to present their "best reasoned judgment" on an issue by learning the appropriate information for their position as well as the opposing argument (Johnson \& Johnson, 2009). The instructor oversees the controversy and monitors the groups as they progress through the five steps outlined by Johnson and Johnson (2007):

1. Research and prepare a position. Each pair develops the position assigned, learns relevant information about it, and plans how to present the best case possible to the other pair. Student pairs are encouraged to compare notes with other pairs representing the same position.

2. Present and advocate their position. Each pair makes a presentation to the opposing pair, with each member of the pair participating. Students are to be as persuasive and convincing as possible. Members of the opposing pair are encouraged to take notes, listen carefully to learn the information being presented, and clarify anything they do not understand.

3. Engage in an open discussion and free discussion. Students argue forcefully and persuasively for their position, presenting as many facts as they can to support their point of view. Following a set of rules to help them criticize ideas without criticizing people, members analyze and critically evaluate the information, rationale, and inductive and deductive reasoning of the opposing pair while rebutting attacks on their position.

4. Reverse perspective. The pairs reverse perspectives and present each other's positions. In arguing for the opposing position, students must be forceful and persuasive, adding any new information the opposing pair did not think to present. They strive to see the issue from both perspectives simultaneously.

5. Synthesize and integrate the best evidence and reasoning into a joint position. The four members of the group drop all advocacy, synthesizing and integrating what they know into factual and judgmental conclusions summarized into a joint position on which all sides can agree. (p. 5)

There have been several findings of achievement benefits associated with academic controversy. Johnson and Johnson (1988) found that when compared to individualist learning, the use of academic controversy results in greater retention of the subject matter. Additionally, it was determined that students demonstrated greater content mastery. These findings were recently supported by the author's 2009 meta-analysis in which the effect size between academic controversy and individualistic learning was reported as 0.76 (Johnson \& Johnson, 2009). Specifically, Johnson and Johnson (2009) found that the use of controversy resulted in a significantly greater ability to recall the information and reasoning contained in one's own and others' positions, more skillful transferring of such efforts to new situations, and greater generalization of principles learned to a wider variety of situations. (pp. 45-47)

Johnson and Johnson (2007) hypothesize that the achievement benefits result from the uncertainty that is created when individuals are presented with ideas or concepts that aren't in alignment with their current knowledge. As creators of the academic controversy model, Johnson and Johnson (2007) provide the following theoretical process: 
1. When individuals are presented with a problem to solve or decision to make, they reach an initial conclusion based on categorizing and organizing incomplete information, their limited experiences, and their specific perspective.

2. When individuals present their conclusion and its rationale to others, they engage in cognitive rehearsal, deepen their understanding of their position, and discover higher-level reasoning strategies.

3. When individuals are confronted by other people with different conclusions based on other people's information, experiences, and perspectives, they become uncertain as to the correctness of their views. A state of conceptual conflict or disequilibrium is aroused.

4. Uncertainty, conceptual conflict, or disequilibrium motivates an active search for more information, new experiences, and a more adequate cognitive perspective and reasoning process (i.e., epistemic curiosity) in hopes of resolving the uncertainty. The search stimulates divergent attention and thought.

5. By adapting their cognitive perspective and reasoning through understanding and accommodating the perspective and reasoning of others, individuals derive a new, reconceptualized, and reorganized conclusion. They detect novel solutions and decisions that, on balance, are qualitatively better. (pp. 23-24)

\section{METHODOLOGY}

The study utilized a pretest-posttest quasi-experimental design in order to explore the student learning effects of academic controversy. The population of the study consisted of post-secondary students enrolled in two sections of macroeconomics at a Mid-Atlantic community college. In order to identify changes in student learning and critical thinking, the Test of Understanding in College Economics (TUCE) was administered as a pretest and posttest to participants with one section acting as a control group and the other section as an experimental group. The students enrolled in the control group received traditional lecture, while the experimental group received lessons that focused on academic controversy as the main instructional method. Both the control (traditional lecture) and experimental (academic controversy) groups were taught by the researcher.

\section{Problem Statement \& Hypothesis}

The study was conducted with the following problem statement guiding the process: Is there evidence to support the claim that the use of academic controversy improves student learning in macroeconomics? To focus the study, the guiding problem statement was divided into the following specific research question and hypotheses:

Are differences in learning found for students taught with academic controversy lessons versus traditional economic instruction, as measured by the overall score on the TUCE?

Null Hypothesis: There will be no significant difference in overall scores on the TUCE for students taught with academic controversy lessons versus traditional economic instruction. $\mathrm{H}_{0}: \mu_{1}-\mu_{2}=0$

Alternative Hypothesis: There will be significant differences in overall scores on the TUCE for students taught with academic controversy lessons versus traditional economic instruction. $\mathrm{H}_{\mathrm{a}}: \mu_{1}-\mu_{2} \neq 0$

Instructional method, consisting of two categories-traditional and experimental, was the independent variable in the study. The traditional method consisted of class lectures while the experimental method involved the use of academic controversy instruction. The dependent variable in this study was student learning as measured by the overall score on the TUCE.

\section{Experimental Treatments}

Over the course of the spring 2010 semester, students enrolled in the experimental group received eight academic controversy lessons. Scheduled approximately every two weeks, students received the academic controversy lesson pack on Tuesdays, while the cooperative learning groups were held in-class on Thursdays. In order to acclimate students to the academic controversy format, a sample lesson was conducted. This involved a discussion of the process, the rules, and student expectations as well as educating the students on the concept of civil discourse. 
The lesson pack was based on the procedure outlined by Johnson and Johnson $(1993,2007)$. It contained an issue page consisting of the question to be investigated and the steps to conduct the controversy. The next page detailed the rules that were to be followed when working in the student groups. Background on the issue was presented along with the key terms and potential resources on the third page. Each packet also contained two pages for students to write out their research notes, position notes, and consensus notes. The final two pages contained the rubrics used for scoring the assignments.

After receiving the lesson packs, students were assigned a position on the lesson topic and asked to learn the facts and to prepare a position. This was to be completed outside of the classroom. A list of potential sources was provided, however, students were also instructed to find their own credible resources.

In class, cooperative learning groups consisting of student quads were used, with two students assigned to each position. This format is recommended when discussions or problem solving is the objective (O'Donnell \& O'Kelly, 1994). Each student pair met at the onset of class to discuss and formulate the strongest argument for their assigned positions. Once this was completed, the student pairs took turns presenting their case to one another. When one group was presenting, the other group was to listen critically, take notes and clarify any information not fully understood. When each pair had presented their assigned position, time was allotted for students to counter the opposing position and to rebut against the reasoning of the other side.

Students were then instructed to reverse sides and present the opposing perspective. This was to be based on the notes taken during the previous steps as well as on any information they may have collected. The aim of this step was to help students see the issues from multiple perspectives at the same time (Johnson and Johnson, 2007). Once both student pairs had presented, arguments from both positions were to be integrated into a synthesized position representing consensus. If consensus could not be reached, students were encouraged to further debate where the differences lie.

Upon completion of the in-class session, students turned in their lesson pack, including their position notes and resources. Additionally, each student quad was responsible for writing a report explaining the synthesis, their rational and providing a logical presentation of the supporting evidence. Both the in-class cooperative group work and the group paper were scored on a rubric developed from guidelines stemming from Harvard University (Goodrich, 1997). Students were also assessed individually on the controversy topics via class examinations.

\section{Analysis}

Data analysis was conducted using SPSS with the independent sample t-test being used to evaluate the research question in the study. This sought to identify the performance of the experimental group in relation to the control group. To ascertain whether the t-test assumption of homogeneity of variance was met by the study, a Levene's test was conducted in conjunction with the t-test analysis.

\section{RESULTS}

Table one provides an overview of the participant characteristics for this study. A total of 34 students participated with 17 students in each instructional group. Both the control and experimental group consisted of 6 females $(35.3 \%)$ and 11 males $(64.7 \%)$. 
Table 1. Participant Characteristics

\begin{tabular}{|c|c|c|c|c|c|c|}
\hline & \multicolumn{2}{|c|}{ Control } & \multicolumn{2}{|c|}{ Experimental } & \multicolumn{2}{|c|}{ Total } \\
\hline & $n$ & $\%$ & $n$ & $\%$ & $n$ & $\%$ \\
\hline & 17 & 100 & 17 & 100 & 34 & 100 \\
\hline \multicolumn{7}{|l|}{ Gender } \\
\hline Male & 11 & 64.7 & 11 & 64.7 & 22 & 64.7 \\
\hline Female & 6 & 35.3 & 6 & 35.3 & 12 & 35.3 \\
\hline \multicolumn{7}{|l|}{ Age } \\
\hline $17-19$ & 5 & 29.4 & 6 & 35.3 & 11 & 32.4 \\
\hline $20-22$ & 7 & 41.2 & 6 & 35.3 & 13 & 38.2 \\
\hline $23-25$ & 4 & 23.5 & 3 & 17.6 & 7 & 20.6 \\
\hline $26 \&$ older & 1 & 5.9 & 2 & 11.8 & 3 & 8.8 \\
\hline \multicolumn{7}{|l|}{ Ethnicity } \\
\hline African-American & 1 & 5.9 & 1 & 5.9 & 2 & 5.9 \\
\hline Caucasian & 16 & 94.1 & 15 & 88.2 & 31 & 91.2 \\
\hline Asian & 0 & 0 & 1 & 5.9 & 1 & 2.9 \\
\hline \multicolumn{7}{|l|}{ Year in College } \\
\hline Freshman & 7 & 41.2 & 9 & 52.9 & 16 & 47.1 \\
\hline Sophomore & 8 & 47.1 & 7 & 41.2 & 15 & 44.1 \\
\hline Continuing & 2 & 11.8 & 1 & 5.9 & 3 & 8.8 \\
\hline \multicolumn{7}{|l|}{ Student Status } \\
\hline Full-time & 15 & 88.2 & 14 & 82.4 & 29 & 85.3 \\
\hline Part-time & 2 & 11.8 & 3 & 17.6 & 5 & 14.7 \\
\hline
\end{tabular}

Students were largely between the ages of 17 and $25(91.2 \%)$ with only $8.8 \%$ of the participants indicating that they were over the age of 26 . With regards to student status, approximately $88.2 \%$ of control group identified themselves as full time in comparison to $82.4 \%$ of students in the experimental group. Finally, the control group consisted of 1 African-American (5.9\%) student and 16 Caucasian (94.1\%) students. By comparison, 1 AfricanAmerican (5.9\%) student, 15 Caucasian (88.2\%) students, and 1 Asian (5.9\%) student made up the experimental group.

\section{Pretest}

In order to ensure equivalent economic knowledge prior to the beginning of the study, the TUCE was administered as a pre-test. Table two illustrates the pretest score statistics from the traditional lecture and academic controversy groups. An independent samples t-test was conducted with a null hypothesis of no difference between the pretest means of the two groups: $\mathrm{H}_{0}: \mu_{1}-\mu_{2}=0$.

Table 2. Pretest Statistics

\begin{tabular}{lllccc}
\hline & \multicolumn{1}{c}{ Group } & N & Mean & Std. Deviation & Std. Error Mean \\
\hline Pretest Score & $\begin{array}{l}\text { Traditional } \\
\text { Lecture }\end{array}$ & 17 & 8.59 & 2.90 & .70 \\
\hline & $\begin{array}{l}\text { Academic } \\
\text { Controversy }\end{array}$ & 17 & 8.71 & 3.46 & .84 \\
\hline
\end{tabular}

The results, found below in table three, indicate that the null hypothesis cannot be rejected. In other words, the traditional lecture group $(\mathrm{M}=8.59, \mathrm{SD}=2.90)$ and the academic controversy group $(\mathrm{M}=8.71, \mathrm{SD}=3.46), \mathrm{t}(32)$ $=.11, \mathrm{p}=.92 \mathrm{had}$ similar knowledge of economics at the onset of the study. 
Table 3. Pretest Independent Samples $t$-test

\begin{tabular}{|c|c|c|c|c|c|c|c|c|c|}
\hline & & & \multicolumn{3}{|c|}{$\begin{array}{c}\text { Levene's Test } \\
\text { for Equality of Variances }\end{array}$} & \multicolumn{4}{|c|}{$t$-test for Equality of Means } \\
\hline & \multirow[b]{2}{*}{$\mathrm{F}$} & \multirow[b]{2}{*}{ Sig. } & \multirow[b]{2}{*}{$t$} & \multirow[b]{2}{*}{$\mathrm{df}$} & \multirow[b]{2}{*}{$\begin{array}{l}\text { Sig. } \\
\text { 2-tailed }\end{array}$} & \multirow[b]{2}{*}{$\begin{array}{c}\text { Mean } \\
\text { Difference }\end{array}$} & \multirow[b]{2}{*}{$\begin{array}{l}\text { Std. Error } \\
\text { Difference }\end{array}$} & \multicolumn{2}{|c|}{$\begin{array}{c}95 \% \text { Confidence Interval } \\
\text { of the Difference }\end{array}$} \\
\hline & & & & & & & & Lower & Upper \\
\hline $\begin{array}{l}\text { Equal Variances } \\
\text { Assumed }\end{array}$ & 2.12 & .16 & .11 & 32 & .92 & -.12 & 1.10 & -2.35 & 2.11 \\
\hline
\end{tabular}

\section{Research Question}

The research question for the study was "Are differences in learning found for students taught with academic controversy lessons versus traditional economic instruction, as measured by the overall score on the TUCE?" The descriptive statistics from the research question can be found in Table 4.

The overall scores ranged from 8.0 to 27.0 with the highest possible overall score being 30 . The scores from the traditional lecture group ranged from 8.0 to 23.0 with a group mean of 14.29 . The academic controversy group scores, on the other hand, ranged from 9.0 to 27 . The controversy group mean on the overall score was 18.35 .

Table 4. Post-Test Student Learning Score Comparison

\begin{tabular}{lllccr}
\hline & \multicolumn{1}{c}{ Group } & N & Mean & Std. Deviation & Std. Error Mean \\
\hline \multirow{2}{*}{ Overall Score } & Traditional Lecture & 17 & 14.29 & 4.41 & 1.07 \\
& Academic Controversy & 17 & 18.35 & 5.17 & 1.25 \\
\hline
\end{tabular}

For student learning, the null hypothesis is rejected in favor of the alternative hypothesis that differences exist in the means of the traditional lecture and academic controversy groups. In other words, students receiving the academic controversy treatment $(\mathrm{M}=18.35, \mathrm{SD}=5.17)$ significantly outperformed the students who received traditional lecture $(\mathrm{M}=14.29, \mathrm{SD}=4.41), \mathrm{t}(32)=2.46, \mathrm{p}=.02$. Table 5 illustrates additional detail regarding the results of the independent samples $t$-test.

Table 5. Independent Samples t-test for Student Learning

\begin{tabular}{|c|c|c|c|c|c|c|c|c|c|}
\hline & \multicolumn{5}{|c|}{$\begin{array}{c}\text { Levene's Test } \\
\text { for Equality of Variances }\end{array}$} & \multicolumn{4}{|c|}{-test for Equality of Means } \\
\hline & \multirow[b]{2}{*}{$\mathrm{F}$} & \multirow[b]{2}{*}{ Sig. } & \multirow[b]{2}{*}{$t$} & \multirow[b]{2}{*}{$\mathrm{df}$} & \multirow[b]{2}{*}{$\begin{array}{l}\text { Sig. } \\
\text { 2-tailed }\end{array}$} & \multirow[b]{2}{*}{$\begin{array}{c}\text { Mean } \\
\text { Difference }\end{array}$} & \multirow[b]{2}{*}{$\begin{array}{l}\text { Std. Error } \\
\text { Difference }\end{array}$} & \multicolumn{2}{|c|}{$\begin{array}{c}95 \% \text { Confidence Interval } \\
\text { of the Difference }\end{array}$} \\
\hline & & & & & & & & Lower & Upper \\
\hline $\begin{array}{l}\text { Equal Variances } \\
\text { Assumed }\end{array}$ & .45 & .51 & 2.46 & 32 & .02 & -4.06 & 1.65 & -7.42 & -.70 \\
\hline
\end{tabular}

\section{DISCUSSION}

The $t$-test results, displayed above, tend to support the idea that academic controversy can be used to produce achievement benefits in students (Kohlberg 1969; Flavell, 1968; Johnson \& Johnson, 1979, 1989, 2000, 2007, 2009). In-line with this study, previous research also indicated that the use of academic controversy resulted in greater retention of the subject matter along with increased ability to recall information and generalize principles learned to a variety of situations (Johnson \& Johnson, 2009). Further, the achievement benefits of cooperative learning techniques identified by McKinney and Graham-Buxton (1993) and Slavin (1983 \& 1990) are also supported by this finding.

It is believed that the statistically significant increase in student learning was the result of the differences between the academic controversy process and traditional lecture. Lecture is considered a passive technique that serves as a delivery tool which is primarily for teaching, not necessarily learning (Sutherland \& Badger, 2004; Jones, 2007). The academic controversy approach motivates students through active participation. When faced with 
information not congruent with their own understanding, students are put into a state of conceptual conflict which unleashes their epistemic curiosity. In an effort to resolve the conceptual conflict, students actively seek out new information which results in a more complete understanding of the topic or concept at hand (Johnson \& Johnson, 2009).

Supporters of both the Piagetian theory of cooperative learning and the academic controversy model contend that students can achieve a better understanding through the use of cognitive conflict (O'Donnell \& O'Kelly, 1994, Johnson \& Johnson, 1996). The statistically significant finding for this study not only lends support for these theories, but also the work of developmental psychologists Kohlber (1969) and Flavell (1968) who felt that logical thinking and cognitive development were the result of the interpersonal controversies that evolve from the consideration of the views of others (Johnson \& Johnson, 2007).

These findings suggest that student's economic course learning can be increased through the use of the academic controversy method. This study adds to the existing literature by providing a framework for economic practitioners that shows promise for improving the low learning outcomes identified in the literature. As such, academic controversy appears to be a technique that can be used to make economics instruction a little less dismal and a lot more motivating.

\section{AUTHOR INFORMATION}

Craig F. Santicola is currently the Director of Business Programs and an Assistant Professor of Economics and Business at Westmoreland County Community College. His research interests focus on market efficiency, stock repurchases, enhancing student learning and critical thinking in economics and finance instruction, and education administration. He currently resides in Western Pennsylvania and can be reached via email at santicolac@wccc.edu.

\section{REFERENCES}

Becker, W. \& Watts, M. (1996). Chalk and talk: A national survey on teaching undergraduate economics. American Economic Review, 86 (2), 448-453.

Becker, W. \& Watts, M. (2008). A little more than chalk and talk: Results from a third national survey of teaching methods in undergraduate economics courses. Journal of Economic Education, 39 (3), 273-286.

Cashin, W. (1990). Students do rate different academic fields differently. In M. Theall and J. Frankline, eds. Student ratings of instruction: Issues for improving practice. New Directions for Teaching and Learning, 43(Fall). San Francisco: CA: Jossey Bass, 113-121.

Colander, D. \& McGoldrick, K. (2009). Educating Economists: The teagle discussion on re-evaluating the undergraduate economics major. Northampton, MA: Edward Elgar.

Flavell, J. (1968). The development of role-taking and communitcation skills in children.

New York, NY: Wiley.

Goodrich, H. (1997). Understanding rubrics. Educational Leadership, 54 (4), 14-17.

Hansen, W.L., Salemi, M.K., \& Siegfried, J.J. (2002). Use it or lose it: Teaching economic literacy. American Economic Review, 92 (2), 463-472.

Johnson, D. \& Johnson, R. (1979). Conflict in the classroom: Controversy and learning.

Review of Educational Research, 49, 51-61.

Johnson, D. \& Johnson, R. (1988). Critical thinking through structured controversy. Educational Leadership, 45 (8), $58-64$.

Johnson, D. \& Johnson, R. (1989) Cooperation and competition: Theory and research. Edina, MN: Interaction Book Company.

Johnson, D. \& Johnson, R. (1993). Creative and critical thinking through academic controversy. The American Behavioral Scientist, 37 (1), 40-53.

Johnson, D., \& Johnson, R. (2000). Cooperative Learning Methods: A Meta-Analysis. Retrieved June 19, 2010 from http://www.co-operation.org/pages/cl-methods.html.

Johnson, D., \& Johnson, R. (2000). Civil political discourse in a democracy: The contribution of psychology. Retrieved May $17^{\text {th }}, 2010$ from http://www.co-operation.org/pages/contro-pol.html. 
Johnson, D. \& Johnson, R. (2007) Creative controversy: Intellectual challenge in the classroom (4 ${ }^{\text {th }}$ ed). Edina, MN: Interaction Book Company.

Johnson, D. \& Johnson, R. (2009). Energising learning: The instructional power of conflict. Educational Researcher, 38 (1), 37-51.

Jones, S. (2007). Reflections on the lecture: Outmoded medium or instrument of inspiration? Journal of Further and Higher Education, 31(4), 397-406.

Kohlberg, L. (1969). Stage and sequence: The cognitive-developmental approach to

socialization. In D. Goslin (Ed). Handbook of socialization theory and research (p. 347-480). Chicago, IL: Rand McNally.

McKinney, K. \& Graham-Buxton, M. (1993). The use of collaborative learning groups in the large class: Is it possible? Teaching Sociology, 21(4), 403-408.

O’Donnell, A. \& O'Kelly, J. (1994). Learning from peers: Beyond the rhetoric of positive results. Educational Psychology Review, 6, 321-350.

Siegfried, J., Bartlett, R., Hansen, W., Kelley, A., McCloskey, D. \& Tietenberg, T. (1991). The status and prospects of the economics major. Journal of EconomicsEducation, 22 (3), 197-224.

Siegfried, J., Bartlett, R., Hansen, W., Kelley, A., McCloskey, D. \& Tietenberg, T. (1991). The economics major: Can and should we do better than a B-? Teaching College Economics, 81(2), 20-25.

Slavin, R. (1983). Cooperative learning. New York, NY: Longman.

Slavin, R. (1990) Cooperative learning: Theory, research and practice. Boston, MA: Allyn and Bacon.

Sutherland, P. \& Badger, R. (2004). Lecturers' perceptions of lectures. Journal of Further and Higher Education, 28(3), 277-289.

Walstad, W. \& Rebeck, K. (2002). Assessing the economic knowledge and economic opinions of adults. Quarterly Review of Economics and Finance, 42(5), 921-935. 